\title{
The Development of a Service-Learning Outcomes Measurement Scale (S-LOMS)
}

\author{
Robin Stanley Snell ${ }^{1}$ and Ka Hing Lau ${ }^{2}$ \\ ${ }^{1}$ Department of Management, Lingnan University, ${ }^{2}$ Office of Service-Learning, Lingnan University \\ Cite as: Snell, R.S., \& Lau, K.H. (2020). The Development of a Service-Learning Outcomes Measurement Scale \\ (S-LOMS). Metropolitan Universities, 31(1), 44-77. DOI: 10.18060/23258
}

This is an open access article distributed under the terms of the Creative Commons Attribution License.

Editor: Valerie L. Holton, Ph.D.

\begin{abstract}
Service-learning as a transformative pedagogy has been adopted within Hong Kong's tertiary education sector for over a decade; however, the lack of a standardized and validated measurement instrument to assess its student learning outcomes has been an obstacle to its further development. The current research study, collaboratively conducted by Lingnan University, The Hong Kong Polytechnic University, Hong Kong Baptist University, and The Education University of Hong Kong, therefore aims to develop such a measurement instrument named the "ServiceLearning Outcomes Measurement Scale (S-LOMS)," taking consideration of the unique features of service-learning in Hong Kong. The scale development and validation work, with exploratory factor analysis and reliability test, has thus far demonstrated that the student-perceived learning outcomes after service-learning can be measured and assessed through 56 items. These items cover 11 domains under four major categories, namely: a) knowledge application; b) personal and professional skills, including relationship and team skills, creative problem solving skills, self-reflection skills, and critical thinking skills, c) civic orientation and engagement, including sense of social responsibility, community commitment and understanding, and caring and respect, and d) self-awareness, including self-efficacy, self-understanding, and commitment to self-improvement. Several additional insights arising from the validation results are discussed.
\end{abstract}

Keywords: Hong Kong, validation, scale development, exploratory factor analysis 


\section{Overview}

The rise of service-learning in tertiary education

Service-learning has been undergoing continuing development in tertiary education, since its very first establishment in the United States in 1960s when Oak Ridge Associated Universities (ORAU) and the Southern Regional Education Board (SREB) developed and popularized service-learning internships (Giles \& Eyler, 1994; Ramsay, 2017). Service-learning has been introduced to tertiary education institutions around the globe, yet while it has evolved in response to diverse contexts, its core principle of connecting academic learning with meaningful service to society has remained constant. Accordingly, there is broad agreement on the definition of service-learning as "a form of experiential education in which students engage in activities that address human and community needs together with structured opportunities for reflection intentionally designed to promote student learning and development” (Jacoby, 1996). There is also broad agreement that service-learning seeks mutual empowerment through social exchange between the students and the served, through which both sides can learn and grow (Shumer, Stanton, \& Giles, 2017), resulting in both academic and non-academic enhancement for students as expected outcomes. Many Hong Kong based tertiary education institutions have come to regard service-learning as potentially beneficial for student learning and development, and have incorporated it in their undergraduate curricula. The first to do so was Lingnan University, which introduced service-learning in 2004, and was also the first university in Asia to institutionalize service-learning by establishing an Office of Service-Learning in 2006 (Ma \& Chan, 2013).

\section{A research gap regarding student learning outcomes from service-learning in Hong Kong}

Although service-learning has been adopted in Hong Kong for over a decade, research on its impacts there and in other Chinese contexts is limited (Shek \& Chan, 2013). In order to further develop service-learning pedagogy in Hong Kong, the benefits for students, if any, of engagement in service-learning, especially evidence about perceived learning outcomes, should be clearly demonstrated to schools and instructors. Although a considerable amount of research documenting student learning outcomes from service-learning has accumulated in the west (e.g. Astin et al., 2000; Celio et al., 2011; Conway et al., 2009; Eyler \& Giles, 1999; Novak et al., 2007; Warren, 2012; Yorio \& Ye, 2012), there are relatively few scholarly publications about developmental outcomes of service-learning in Asia, including Hong Kong, a gap that needs to be filled (Xing \& Ma, 2010).

This research gap can be partly attributed to the lack of locally salient and reliable measurement instruments for assessing the effectiveness of service-learning in Hong Kong, as explained in a later section. Two research approaches have thus far been adopted, both of which have both fallen short of filling the research gap. First, some studies have adopted qualitative methods,

(C) The Author 2020. Published by the Coalition of Urban and Metropolitan Universities. www.cumuonline.org 
such as focus groups and interviews (e.g. Shek \& Chan, 2013; Snell et al., 2015a, 2015b, 2019). Although these approaches have offered deep and comprehensive insights into student experiences, as well as design and implementation issues during service-learning, it is difficult to compare qualitative findings across different studies (Toncar et al., 2006). Second, while other studies have used quantitative surveys for assessing learning outcomes, these have adopted or translated measurement scales that were developed in the west (e.g. Lo et al., 2016; Ngai, 2006, 2009; Siu et al., 2013), and/or have focused on outcome domains that reflect researcher interests rather than local institutional priorities.

This study, therefore, seeks to fill the research gap by developing a standardized and validated measurement instrument named "Service-Learning Outcomes Measurement Scale (S-LOMS)" for assessing the perceived learning outcomes of students engaged in service-learning in Hong Kong, which addresses outcome domains that match local institutional priorities, and which can generate results that are comparable across studies in Hong Kong and potentially more broadly in Asia. An additional aim of the research is to reduce error that might otherwise arise from using items and scales that have been developed in the west, and which may contain slang, idioms, and allusions that are not fully understood by local students. We believe that a customized measurement instrument can serve as a reliable means for schools and instructors to evaluate servicelearning pedagogy, while also generating a robust body of evidence regarding the local educational benefits of service-learning, which, if favorable, could attract newcomers to adopt servicelearning pedagogy.

The next section will develop a preliminary conceptual framework for analyzing student developmental outcomes arising from service-learning, based on a review of western literature. This is followed by a section on how service-learning has been customized to address local needs in Hong Kong, in the context of (a) broader educational reforms and (b) cultural and institutional values that appear to be more closely aligned with Confucian ideals than with western principles of liberation and democracy. These review sections are followed by a synthesis, in which we present a modified, culture-sensitive conceptual framework for analyzing student developmental outcomes arising from service-learning in Hong Kong. We then go on to explain the methods adopted for the development of a new measurement instrument for assessing student-learning outcomes, including how items and scales were created and validated, and how the associated statistical analysis was conducted. This methods section is followed by one that reports our results, and the paper concludes a discussion of the insights from our findings and analysis. 


\section{Literature Review}

Preliminary conceptual framework for students' developmental outcomes from service-learning

The developmental outcomes for students that arise from service-learning have been studied extensively in the west, and numerous outcome lists have been proposed. For example, stating that service-learning "aims to connect the personal and intellectual, to help students acquire knowledge that is useful in understanding the world, (and) build critical thinking capacities" (Eyler \& Giles, 1999) identified learning outcomes within four domains. These domains are: 1) understanding and applying knowledge; 2) personal and interpersonal development; 3) cognitive development, including critical thinking, engagement curiosity, reflective practice, and perspective transformation; and 4) citizenship. The above framework broadly matches other conceptualizations, such as one by Driscoll et al. (1996), and has also been reflected in subsequent analyses by Eyler et al. (2001), Ash \& Clayton (2009), and Felten \& Clayton (2011).

We consider, nonetheless, that the Eyler \& Giles (1999) four-domain framework can be condensed into three by subsuming personal and interpersonal development, such as team and interpersonal skills, together with cognitive development, such as critical thinking, under the broader domain of personal growth. Table 1, as below, locates prior conceptual frameworks for student learning outcomes within the three major domains of academic enhancement, personal growth, and civic learning, which concurs with the model proposed by Felten and Clayton (2011).

Table 1. A preliminary conceptual framework for student learning outcomes from servicelearning

\begin{tabular}{|c|c|c|c|}
\hline Researchers & $\begin{array}{l}\text { Academic } \\
\text { Enhancement }\end{array}$ & Personal Growth & Civic Learning \\
\hline $\begin{array}{l}\text { Eyler and Giles } \\
\text { (1999) }\end{array}$ & $\begin{array}{l}\text { Understanding } \\
\text { and applying } \\
\text { knowledge }\end{array}$ & $\begin{array}{l}\text { Personal and Interpersonal } \\
\text { development } \\
\text { Critical thinking } \\
\text { Reflective practice } \\
\text { Perspective transformation } \\
\text { Engagement, curiosity }\end{array}$ & Citizenship \\
\hline $\begin{array}{l}\text { Driscoll et al. } \\
\text { (1996) }\end{array}$ & $\begin{array}{l}\text { Academic } \\
\text { achievement }\end{array}$ & $\begin{array}{l}\text { Personal development } \\
\text { Communication skills } \\
\text { Career choices } \\
\text { Self-awareness } \\
\text { Autonomy/ independence } \\
\text { Sense of ownership }\end{array}$ & $\begin{array}{l}\text { Awareness of commu- } \\
\text { nity } \\
\text { Involvement with com- } \\
\text { munity } \\
\text { Commitment to service } \\
\text { Sensitivity to diversity }\end{array}$ \\
\hline Eyler et al. (2001) & $\begin{array}{r}\text { Enhanced aca- } \\
\text { demic results }\end{array}$ & $\begin{array}{l}\text { Interpersonal development } \\
\text { Ability to work with others }\end{array}$ & $\begin{array}{l}\text { Moral development } \\
\text { Reduced stereotyping } \\
\text { and prejudice }\end{array}$ \\
\hline
\end{tabular}

(C) The Author 2020. Published by the Coalition of Urban and Metropolitan Universities. www.cumuonline.org 


\begin{tabular}{|c|c|c|c|}
\hline & $\begin{array}{l}\text { Knowledge ap- } \\
\text { plication }\end{array}$ & $\begin{array}{l}\text { Leadership and communi- } \\
\text { cation skills } \\
\text { Problem analysis } \\
\text { Critical thinking skills } \\
\text { Personal efficacy } \\
\text { Personal identity } \\
\text { Career development } \\
\text { Spiritual growth }\end{array}$ & $\begin{array}{l}\text { Enhanced cultural \& } \\
\text { racial understanding } \\
\text { Sense of social respon- } \\
\text { sibility } \\
\text { Citizenship skills } \\
\text { Commitment to service }\end{array}$ \\
\hline $\begin{array}{l}\text { Ash and Clayton } \\
(2009)\end{array}$ & $\begin{array}{c}\text { Academic en- } \\
\text { hancement }\end{array}$ & Personal growth & Civic learning \\
\hline $\begin{array}{l}\text { Felten \& Clayton } \\
\text { (2011) }\end{array}$ & $\begin{array}{l}\text { Academic } \\
\text { knowledge/ } \\
\text { skills/ disposi- } \\
\text { tions }\end{array}$ & $\begin{array}{l}\text { Personal growth } \\
\text { Teamwork } \\
\text { Critical thinking skills } \\
\text { Intercultural competence }\end{array}$ & Civic learning \\
\hline
\end{tabular}

The tripartite categorization in Table 1 is consistent with Eyler's (2010) review, which confirmed that service-learning had favorable impacts on college students in terms of academic enhancement, personal growth, and outcomes relating to civic engagement. A large body of prior research accordingly indicates that service-learning can enhance students' learning within the three broad domains. Relevant sources include: Astin \& Sax (1998), Celio et al. (2011), Conway et al. (2009), Driscoll et al. (1996), Felten \& Clayton (2011), Lundy (2007), Novak et al. (2007), Prentice (2007), Richard et al. (2017), Rama (1998), Shek \& Chan (2013), Simon \& Cleary (2006); Snell et al. (2015a), Warren (2012), Yorio \& Ye (2012). While we consider that these three domains capture most of the salient outcomes, space constraints mitigate providing a detailed mapping of all prior research.

Local adaptation of service-learning to Hong Kong

Since the institutionalization of service-learning in Asia (including Hong Kong) has been relatively recent (Permaul, 2010), it is not as mature as in the United States (Ma \& Lo, 2016). As mentioned above, the tertiary education institutions in Hong Kong did not begin to incorporate service-learning within their curricula until the 21st century. The development of service-learning in Hong Kong (see Ma, 2018) cannot be fully understood without taking local education policy reforms and associated institutional ideologies into account.

The context of broader educational reforms. Regarding the educational policy reforms, three milestones facilitated the emergence of service-learning. First, in 2001 a HKSAR government report critically reviewed Hong Kong's school curriculum and set out a vision about equipping students with 21st century skills and abilities, with the cultivation of whole-person development and lifelong learning as core educational goals (Education and Manpower Bureau, 2001). This 
report foreshadowed curriculum reforms of secondary and tertiary education at the beginning of 21st century. The new emphasis on whole-person development provided a supportive backdrop for the development of service-learning in Hong Kong (Xing \& Ma, 2010).

Second, in 2010, the University Grants Committee (UGC), the organization responsible for guiding the HKSAR government on the funding and strategic development of all public-funded universities in Hong Kong, reiterated its overall mission for universities in Hong Kong. This mission, which is well-matched with the aims of service-learning, sought to develop students into productive and socially responsible citizens by equipping them with "a greater sense of the wider world and the moral or ethical tools with which they can contribute to that world. The experience of university (life) should firmly root an individual's sense of personal and social responsibility” (University Grants Committee, 2010).

Third, wide-ranging structural reforms involved changing from a three-year to a four-year system for undergraduate degree programmes by all publicly-funded universities in Hong Kong, beginning in 2012. The adoption of a four-year programme reflected the purpose of providing students with a broader knowledge base to complement more specialized instruction (Education and Manpower Bureau, 2005), and opened up opportunities to include general education as an integral part of the undergraduate curriculum (Freake, 2013).

In conjunction with the 2012 reforms, many Hong Kong universities launched service-learning programs, reflecting their own needs and circumstances (Ma, 2018). The Hong Kong Polytechnic University, for example, seized on the introduction of an extra year in the undergraduate program to stipulate the incorporation of a service-learning component in their graduation requirement (Chan \& Ngai, 2014; Shek et al. 2015).

Orientation by Confucian ideologies. The ideological context for service-learning in Asian societies such as Hong Kong appears to be substantially different from that of the west, where servicelearning has been based on John Dewey's ideas about the role of critical reflection on social action as a vehicle for building democratic values and awareness of human rights (Giles \& Elyer, 1994; Saltmarsh, 2005). Although service-learning may be considered to be an aspect of civic education, Confucian ideologies underpin educational policies in Asian societies, resulting in a relatively depoliticised approach to such education, by emphasising spirituality, self-cultivation, harmonious relationships, and preservation of the status quo (Lee, 2004).

Thus, in Hong Kong, civic education as a whole has emphasised personal and moral development rather than democracy and human rights (Leung \& Yuen, 2012). Accordingly, we observe that, in alignment with this overall approach, the stated objectives and expected learning outcomes of service-learning programs in Hong Kong tertiary education institutions have emphasised knowledge application and practical skills rather than proactive civic engagement or democratic ideals, as illustrated in Table 2 below. By contrast, the service-learning course design

(C) The Author 2020. Published by the Coalition of Urban and Metropolitan Universities. www.cumuonline.org Metropolitan Universities | DOI 10.18060/23858 | February 21, 2020 
handbook (Howard, 2001) developed by the University of Michigan as a reference point for other United States universities, has framed "purposeful civic learning" as an essential characteristic of academic service-learning. This handbook states that "the addition of relevant and meaningful service with the community must not only serve the community and enhance academic learning in the course, but also directly and intentionally prepare students for active civic participation in a diverse democratic society" (Howard, 2001).

(C) The Author 2020. Published by the Coalition of Urban and Metropolitan Universities. www.cumuonline.org 
Table 2. Main Objectives and Expected Learning Outcomes for Major Hong Kong Higher Education Institutions Adopting Service-Learning

\begin{tabular}{|c|c|c|}
\hline University & Objectives & | Expected Learning Outcomes \\
\hline $\begin{array}{l}\text { Chung Chi College, } \\
\text { the Chinese University } \\
\text { of Hong Kong } \\
\text { (http://www.news.ccc. } \\
\text { cuhk.edu.hk/slp/in- } \\
\text { dex_e.php) }\end{array}$ & $\begin{array}{l}\text { 1. To enhance students' personal growth and } \\
\text { prepare them to be informed, responsible citi- } \\
\text { zens and civic leaders, through instilling the set } \\
\text { of core qualities including values, knowledge, } \\
\text { skills, critical and reflective thinking, and com- } \\
\text { mitment, etc. } \\
\text { 2. To benefit society by bringing in high-level } \\
\text { expertise and resources from the tertiary educa- } \\
\text { tion sector that address community needs. } \\
\text { 3. To contribute to academic research on ser- } \\
\text { vice-learning as a subject of study, and its appli- } \\
\text { cation and impacts. }\end{array}$ & $\begin{array}{l}\text { 1. Apply their (discipline) knowledge } \\
\text { and generic skills to address commu- } \\
\text { nity needs; } \\
\text { 2. Acquire skills to work efficiently and } \\
\text { effectively with others; } \\
\text { 3. Evaluate one's own strengths and } \\
\text { limitations, and identify areas that need } \\
\text { further development for personal } \\
\text { growth; } \\
\text { 4. Develop a sense of citizenship and } \\
\text { community service including the culti- } \\
\text { vation of social responsibility, civic en- } \\
\text { gagement, attention and action for the } \\
\text { needy; } \\
\text { 5. Develop information literacy and } \\
\text { foundations for lifelong learning; } \\
\text { 6. Demonstrate active and rational col- } \\
\text { laboration in group discussion; } \\
\text { 7. Demonstrate personal and social soft } \\
\text { skills, and the ability to work in inter- } \\
\text { disciplinary teams; }\end{array}$ \\
\hline $\begin{array}{l}\text { City University of } \\
\text { Hong Kong (CityU) } \\
\text { (http://www.cityu.edu. } \\
\text { hk/caio/oss/) }\end{array}$ & $\begin{array}{l}\text { 1. To enhance students' understanding of the } \\
\text { work environment and their long-term personal } \\
\text { and professional development. } \\
\text { 2. To develop students' important life and job } \\
\text { skills required by future employers so as to en- } \\
\text { hance their lifelong employability. } \\
\text { 3. To facilitate, strengthen, and expand students' } \\
\text { learning through the integration of service-learn- } \\
\text { ing into real life work experience. } \\
\text { 4. To elevate the overall standard of students in } \\
\text { terms of personal, career, and professional ac- } \\
\text { complishments through meaningful campus } \\
\text { work and systematic feedback provided by re- } \\
\text { cruiting units. } \\
\text { 5. To provide a reliable pool of resources sup- } \\
\text { port to departments and individuals who have a } \\
\text { high demand for manpower due to rapid devel- } \\
\text { opment of the University. } \\
\text { 6. To provide opportunities for faculty, students, } \\
\text { and administrative staff to develop sense of be- } \\
\text { longing towards the CityU community. }\end{array}$ & $\begin{array}{l}\text { 1. Personal and professional develop- } \\
\text { ment } \\
\text { 2. Students' important life and job skills } \\
\text { 3. To facilitate, strengthen, and expand } \\
\text { students' learning }\end{array}$ \\
\hline
\end{tabular}

(C) The Author 2020. Published by the Coalition of Urban and Metropolitan Universities. www.cumuonline.org 
Hong Kong Baptist University (https://cisl.hkbu.edu.h k/about-cisl/SLdefinition)
1. Service projects anchored in a specific curriculum are developed to contribute to the common good of humankind in the effort to enrich students' academic learning and personal growth 2. Structured service-learning opportunities are built into academic curricula directly, allowing students to reflect better upon their experience as citizens and whole persons and to conceptualize and enact effective relationships between their academic learning and community service locally, nationally, and globally.
1. Apply their cumulative learning gained from their discipline knowledge/course and beyond to address specific community issues by means of innovation;

2. Demonstrate deep self-understanding, empathy and caring for others and great sense of commitment to the common good of humankind;

3. Develop a habit of critical reflection for life-long and life-wide learning, personal and professional development, and

4. Identify ways to strengthen generic competencies and professional skills.

\begin{tabular}{l}
\hline Lingnan University \\
(SLRS Model Manual,
\end{tabular}
from Chan et al., 2006)

The Polytechnic University of Hong Kong (PolyU)

(https://www.polyu.ed u.hk/osl/index.php?option=com_content\&view=article\&id $=88 \&$ Itemid=218)

The Education University of Hong Kong (https://www.eduhk.hk /re/modules/content/item.php?categoryid=42\&itemid=22)

The University of Hong Kong (in the form of experiential learning) (https://tl.hku.hk/wpcontent/uploads/2014/01/GallantHo-Leaflet-20132.pdf)
1. Offers a real-life opportunity for students to apply the knowledge and skills that they have gained from course work into the community, and to integrate useful knowledge into practice.

2. Students' personal growth, self-fulfillment and satisfaction are expected to be enhanced after joining the service-learning program.

\section{Preparing students to become civic-minded} professionals with a heart to serve.

2. It is expected that service-learning at PolyU will not only enhance students' sense of civic responsibility and engagement, but also benefit the community at large. It emphasizes learning through engagement in services.

3. As a pedagogy, service-learning gives academic learning, service experience and reflection central roles in learning.

1. Subject-related knowledge

2. Communication skills

3. Organizational skills

4. Social competence

5. Problem-solving skills

6. Research skills

1. Apply academic knowledge and skills into meaningful community service

2. Have structured processes for students to reflect critically on academic content and civic engagement, so as to consolidate their academic and ethical development

1. Leadership skills, communication skills, interpersonal skills, organizational skills, influencing skills, problem-solving skills, and creativity

1. The learning objectives are achieved through consistent faculty mentoring and critical reflection of the participation process. Students will see the integration of theory and practice and develop its own interpretation and holistic understanding of the topics.

1. It is a kind of learning that requires students to tackle real-life issues and problems by drawing on theoretical knowledge that they have learnt in the formal curriculum.

2. Dealing with real-life problems requires students to integrate knowledge within and across disciplines, to go beyond technical considerations, and to take into account social and human factors that come into play. 
A review of definitions of civic engagement by Daynes and Wygant (2003) provides a useful reference point. They identified a spectrum of definitions, ranging from those that "work from social justice or progressive models" through those that focus on political action inside or outside the electoral system, including protests, to those assuming non-political community-based work or the expression of individual freedom. The content of Table 2 suggests that service-learning programs in Hong Kong tend to be oriented more toward non-political community-based work than toward political involvement and social justice.

Confucian values also appear to have shaped the design and implementation of service-learning at the course level in Hong Kong. This metropolis, with its strong Confucian influence, has been regarded as a culture with large power distance, where those members who have relatively little power tend to accept hierarchical differentiation and inequalities in relationships, and low uncertainty avoidance, the extent to which those members prefer structure, strong direction and stability over ambiguity, (Hofstede, 1983). Such cultural characteristics have led Hong Kong to adopt authoritarian family-style as an implicit model of organization that follows the Chinese administration principle of governance by man over and above rule of law (Hofstede, 1980). Accordingly, in educational settings, we observe that Chinese students in Hong Kong tend to expect that their instructors will play a major role in structuring and guiding their service-learning projects, an expectation that is consistent with previous research findings that Asian students prefer their courses to involve tight structure and close instructor guidance (e.g. Chan, 1999; Rodrigues, 2005). By contrast, in western contexts, service-learning programs are often framed as opportunities to learn by discovery about participatory democracy, and to build students' ability to take action to change communities with the explicit aim of furthering social justice (Battistoni, 1997; Einfeld \& Collins, 2008; Mitchell, 2008; Wade, 1997).

Besides manifesting a relative lack of emphasis on social justice and democracy, Table 2 also sheds light on another characteristic of service-learning in Hong Kong, which focuses more on the development of practical and job skills. This emphasis is aligned with traditional expectations in Hong Kong (Kennedy, 2002) and in Chinese cultures in general (Lee, 1996) that academic success is a pathway to job success and upward social mobility (Shek \& Chan, 2013).

\section{Synthesis: A modified conceptual framework for the Hong Kong context}

Our review of the literature led us to create a modified conceptual framework that formed the basis for the measurement instrument, S-LOMS, which we subsequently developed. This new framework (see Table 3) comprises 15 domains that are subsumed under the four broad categories of knowledge application, personal and professional skills, civic orientation and engagement, and self-awareness. There are five main differences from the preliminary model.

First, reflecting Hong Kong's pragmatic orientation, we relabeled the original personal growth category as personal and professional skills. Second, we included the domain of self-reflection

(C) The Author 2020. Published by the Coalition of Urban and Metropolitan Universities. www.cumuonline.org 
skills within this broader category to acknowledge the centrality of self-cultivation in Confucian educational philosophy (Lee, 2004). This inclusion is also supported by prior research that has established that reflection plays a key role for students in deriving substantial educational and developmental outcomes from engagement in service-learning (Bringle \& Hatcher, 1999; Eyler \& Giles, 1999; Godfrey et al., 2005; Hatcher et al., 2004; Jacoby, 1996).

Third, we made self-awareness the basis of a fresh category, subsuming the domains of self-understanding, self-esteem, and commitment to self-improvement, once again acknowledging the importance of Confucian self-cultivation (Lee, 2004). Fourth, the domains that are subsumed under our category of civic orientation and engagement reflect the relatively depoliticized approach to civic education in Hong Kong (Leung \& Yuen, 2012), with its muted concern for participatory democracy.

Fifth, we replaced the category label of academic enhancement and renamed the category as knowledge application. In line with this, we dropped subject knowledge from this category, on the grounds that the graded assignments within a course should suffice for systematically measuring how much students gain in terms of subject knowledge.

Table 3. The Modified Conceptual Framework Specific to Hong Kong Context

\begin{tabular}{|c|c|c|c|c|}
\hline $\begin{array}{l}\text { Conceptual } \\
\text { Category }\end{array}$ & $\begin{array}{l}\text { Knowledge } \\
\text { Application }\end{array}$ & $\begin{array}{l}\text { Personal and } \\
\text { Professional } \\
\text { Skills } \\
\end{array}$ & $\begin{array}{l}\text { Civic Orienta- } \\
\text { tion and } \\
\text { Engagement }\end{array}$ & Self-awareness \\
\hline \multirow{6}{*}{$\begin{array}{l}\text { Learning } \\
\text { Outcome } \\
\text { Domain }\end{array}$} & $\begin{array}{l}\text { 1. Knowledge } \\
\text { application }\end{array}$ & $\begin{array}{l}\text { 2. Relationship } \\
\text { skills }\end{array}$ & $\begin{array}{l}\text { 8. Sense of social } \\
\text { responsibility }\end{array}$ & $\begin{array}{l}\text { 13. Self-under- } \\
\text { standing }\end{array}$ \\
\hline & & 3. Team skills & $\begin{array}{l}\text { 9. Commitment to } \\
\text { social betterment }\end{array}$ & $\begin{array}{l}\text { 14. Commitment } \\
\text { to Self-improve- } \\
\text { ment }\end{array}$ \\
\hline & & $\begin{array}{l}\text { 4. Problem-solving } \\
\text { skills }\end{array}$ & $\begin{array}{l}\text { 10. Understanding } \\
\text { community }\end{array}$ & 15. Self-esteem \\
\hline & & $\begin{array}{l}\text { 5. Critical-thinking } \\
\text { skills }\end{array}$ & $\begin{array}{l}\text { 11. Respecting di- } \\
\text { versity }\end{array}$ & \\
\hline & & $\begin{array}{l}\text { 6. Self-reflection } \\
\text { skills }\end{array}$ & $\begin{array}{l}\text { 12. Empathy and } \\
\text { caring for others }\end{array}$ & \\
\hline & & 7. Creativity & & \\
\hline
\end{tabular}

(C) The Author 2020. Published by the Coalition of Urban and Metropolitan Universities. www.cumuonline.org 


\section{Methods}

\section{Development strategies}

The scale development procedures adopted for the new instrument followed the standard approach employed in academic research (e.g. Boateng et al., 2018; DeVellis, 2003). We began with the identification of constructs and domains through literature reviews, as demonstrated in the previous sections. The subsequent item development and scale validation procedures are described below in this methods section and in the results section that follows. Our objective was to establish a validated measurement instrument, i.e. S-LOMS, that fulfilled four criteria: a) applicable in the cultural and institutional contexts of Hong Kong; b) comprehensive in covering commonly desired developmental outcomes arising from service-learning there; c) standardized, so as to be appropriate for service-learning courses and programs across the full range of academic subjects; and d) composed of distinct sub-scales, thus offering institutions and researchers flexibility to create shorter versions, focusing on particular outcome domains.

\section{Item development}

For the most part, we adopted a deductive method for scale development, but this was supplemented by an inductive method. A deductive method involves creating survey items that are based on theory-based definitions of the target domain constructs, following an extensive literature review and a thorough examination of pre-existing scales. Typically, it is adopted when there are established theories about the constructs that are to be measured already existed (Boateng et al., 2018; Hinkin, 1995, Hinkin et al., 1997; Morgado et al., 2017). An inductive method, by contrast, is not theory-based, and involves identifying constructs and establishing the appropriateness of survey items based on the opinions of subject matter experts, collected by means of interviews, focus groups (Hinkin, 1995, Hinkin et al., 1997), or electronic media.

Earlier sections of this paper have reviewed the past literature and have developed a conceptual framework for S-LOMS. In addition, we conducted a review of pre-existing instruments that have been used for assessing developmental outcomes for students arising from service-learning, yet we could only identify a small number of measurement scales for that had been validated in both western and Hong Kong-based studies.

This dearth reflects that even in the west, there are few salient standardized and validated instruments for assessing development outcomes for students, arising from service-learning (Toncar et al., 2006), and that among these, most have been narrowly focused on specific outcome domains (Bringle et al., 2004), such as civic learning (e.g. Eyler et al., 1997; Olney \& Grande 1995), and community self-efficacy (e.g. Reeb et al., 1998). We also examined the Service Learning Benefit scale (SELEB), developed by Toncar et al. (2006), which is atypical in that it encompasses a broad range of self-perceived benefits arising from service-learning. We judged, however, that 
the SELEB may lack reliability because it asks respondents to provide generalized ratings on particular constructs, such as "personal growth" and "skills in learning from experience” without going into specifics or providing conceptual explanations.

As noted earlier in this paper, we found that when assessing self-perceived developmental outcomes arising from service-learning, Hong Kong-based researchers have tended to borrow measurement scales that have been developed in the west. We were only able to identify one preexisting standardized instrument, the so-called common outcomes measure (COM) for assessing a wide range of developmental outcomes arising from service-learning (Ma et al., 2019). This assesses outcomes in nine domains, namely self-understanding/confidence; communication skills; problem-solving skills; civic engagement, social responsibility and willingness to contribute; team skills; self-reflection; general knowledge application; caring for others; and intercultural competence. The COM was initially validated with a relatively small sample $(\mathrm{N}=193)$. We took reference of this generic scale, along with some domain-focused scales found in the prior literature and in use by particular tertiary education institutions in Hong Kong, such as a scale for self-esteem (Rosenberg, 1965)

Once agreement on the conceptual framework for students' developmental outcomes (Table 3) had been reached, we adopted an inductive approach for item development across the 15 constituent domains. First, we formed a panel of local practitioners-cum-researchers, comprising faculty members with service-learning experience from four institutions adopting service-learning pedagogy, namely Lingnan University, The Hong Kong Polytechnic University, Hong Kong Baptist University, and The Education University of Hong Kong. This panel identified a small number of sub-domains for each of the 15 domains, and then engaged in brainstorming sessions to generate potential survey items for the various sub-domains, thereby generating a total of 103 prospective items for a draft S-LOMS.

Second, in line with the recommended approach by DeVellis (2003), these emerging items were evaluated by a different group of subject matter experts (SMEs), who also were experienced service-learning practitioners from the above institutions. The initial panel then reviewed the SMEs' comments before compiling the draft S-LOMS for subsequent item validation, as described next.

\section{Item validation}

Procedure and participants. The draft S-LOMS in English was then subjected to a pilot study, which aimed at testing item readability for the target respondents, namely students studying at tertiary education institutions in Hong Kong. Six pilot sessions were held at the abovementioned institutions through face-to-face administration. Each session lasted about one hour with no more than 20 participants and comprised two parts. In the first part, which was around 40 minutes, the participants were invited to answer the draft S-LOMS and note when they encountered any difficulty in understanding items. In the second part, which was around 20 minutes, the participants

(C) The Author 2020. Published by the Coalition of Urban and Metropolitan Universities. www.cumuonline.org 
were invited to raise any comments they wanted to share with the administrator, about any issue regarding language, such as the use of words or ambiguity when answering the draft S-LOMS. The pilot sessions collected responses from altogether 83 participants, comprising 29 males (34.9\%) and 54 females (65.1\%), with the mean age of 20.5. Their comments shared in the session and written on the draft S-LOMS were then analyzed and discussed by the panel, with the result that two items were discarded, and 35 items were revised in wording in order to enhance readability.

With the revised draft measurement instrument, a validation exercise was implemented to test the psychometric properties, such as underlying dimensionality and internal consistency. S-LOMS was then administered in class on a collective basis. Students were informed of the rationale of this validation exercise and were invited to join voluntarily, and those who did not want to participate could choose to leave. The remaining students were then instructed to indicate their consent and answer the revised S-LOMS, along with some demographical information, including gender, age, major of study, prior service-learning experience, under the assurance of data confidentiality. Each respondent was offered a supermarket gift voucher valued at HK\$50 as a token for their participants upon completing the revised S-LOMS. A total of 400 university full-time students at the four collaborative institutions completed the revised S-LOMS via classroom administration, with 397 of them providing demographic data. Among them, 35.0\% were male respondents while $65.0 \%$ were female respondents, and the mean age was 20.9. They came from various disciplinary backgrounds (Arts: 23.4\%; Social Science: 15.6\%; Business: 22.4\%; Engineering \& Science: 27.5\%; Nursing: 11.1\%). Most respondents, 70.5\%, had previous servicelearning experience.

Multiple methods were adopted to explore the dimensionality of the revised S-LOMS and the stability thereof. First, owing to the large number of measurement items and their underlying domains, the Minimum Average Partials (MAP) test was employed to provide guidance for determining the number of factors under the four categories. The MAP test, which involves principal components analysis with the examination of a series of matrices of partial correlation, is regarded as one of the best methods to obtain optimal solutions to the number of components in factor analysis (O’Connor, 2000). The items within the four categories were inputted into the MAP program developed for SPSS by O'Connor (2000) to obtain the number of optimal factors under each category.

Statistical analysis. Each category's items were then analyzed by Exploratory Factor Analysis (EFA) in IBM SPSS version 23.0 by the specification of the number of factors to that category obtained in the MAP test. Specifically, the Principle Components method with oblimin rotation was employed, given that correlations were expected among domains of the measurement instrument. Two exclusion criteria were adopted in reducing the number of items in the EFA, with the purpose of simplifying the final factor structure. First, any items with the highest factor loading lower than 0.4 in absolute value were removed, given that "one would want in general a variable

(C) The Author 2020. Published by the Coalition of Urban and Metropolitan Universities. www.cumuonline.org Metropolitan Universities | DOI 10.18060/23858 | February 21, 2020 
to share at least $15 \%$ of its variance with the construct (factor) it is going to be used to help name" (Stevens, 2009). Second, any double-loaded items were removed. After exclusion, the EFA was re-administered. In the event that all items obtained satisfactory absolute values of factor loadings, some would be discarded based on the consideration of semantic proximity and the results of item-total correlation. Owing to the large number of tested domains and items, as well as that the four categories were expected to be theoretically distinctive yet empirically related, four sets of EFA were separately performed for the four categories in exploring underlying dimensionality.

\section{Results}

The MAP test results indicated different optimal factor numbers for different categories, specifically one factor for the category of knowledge application, five factors for the category of personal and professional skills, four factors for the category of civic orientation and engagement, and three factors for the category of self-awareness. Table 4 below depicts the results of the four category MAP tests.

Table 4. The MAP Test Results for the Four Categories of the Measurement Instrument

\begin{tabular}{lc}
\hline Category & Optimal Number of Factors \\
\hline Knowledge Application & 1 \\
Personal and Professional Skills & 5 \\
Civic Orientation and Engagement & 4 \\
Self-awareness & 3 \\
\hline
\end{tabular}

The EFAs for determining the factor numbers guided by the above MAP test results for the four categories were then administered by following the afore-mentioned item exclusion and selection procedures. The analysis results indicated a clear factor structure at the higher order with satisfactory factor loadings. Tables 5 to 8 illustrates the resulting S-LOMS by category.

Specifically, the items for the category of knowledge application converged to a single factor with factor loadings between .799 and .881 , with variance explained $72.35 \%(\alpha=.872)$. 
Table 5. Results for the Items of the Category of Knowledge Application

\begin{tabular}{clcc} 
No & \multicolumn{1}{c}{ Item } & $\begin{array}{c}\text { Absolute Value of } \\
\text { Factor Loading }\end{array}$ & $\begin{array}{c}\text { Item-Total } \\
\text { Correlation }\end{array}$ \\
\hline 1 & $\begin{array}{l}\text { I know how to apply what I learn in class to solve } \\
\text { real-life problems. }\end{array}$ & .881 & .771 \\
2 & $\begin{array}{l}\text { I am able to apply/integrate classroom knowledge to } \\
\text { deal with complex issues. }\end{array}$ & .867 & .752 \\
3 & $\begin{array}{l}\text { I know how to transfer knowledge and skills from } \\
\text { one setting to another. }\end{array}$ & .853 & .731 \\
4 & I can make connections between theory and practice.
\end{tabular}

Within the category of personal and professional skills, a four-factor structure emerged in the final result. The four factors are named as creative problem solving skills, comprising the original items of the domains of problem solving skills and creativity, with factor loadings between 472 and $.867(\alpha=.919)$, relationship and team skills, comprising the original items of the domains of relationship skills and team skills, with factor loadings between .470 and .886 $(\alpha=.925)$, self-reflection skills, with factor loadings between .542 and $.838(\alpha=.848)$, and d) critical thinking skills, with factor loadings between .411 and $.732(\alpha=.751)$. The overall variance explained by the category's items was $67.91 \%(\alpha=.961)$. 
Table 6. Results for the Items of the Category of Personal and Professional Skills

\begin{tabular}{|c|c|c|c|c|c|c|}
\hline \multirow[b]{2}{*}{ No } & \multirow[b]{2}{*}{ Item } & \multicolumn{5}{|c|}{ Absolute Value of Factor Loading } \\
\hline & & $\begin{array}{c}\text { Creative } \\
\text { Problem- } \\
\text { Solving } \\
\text { Skills }\end{array}$ & $\begin{array}{c}\text { Relation- } \\
\text { ship and } \\
\text { Team } \\
\text { Skills }\end{array}$ & $\begin{array}{c}\text { Self-re- } \\
\text { flection } \\
\text { Skills }\end{array}$ & $\begin{array}{c}\text { Critical } \\
\text { Thinking } \\
\text { Skills }\end{array}$ & $\begin{array}{l}\text { Item-To- } \\
\text { tal Cor- } \\
\text { relation }\end{array}$ \\
\hline 1 & I am not afraid of trying new things. & .867 & & & & .610 \\
\hline 2 & I am able to generate original ideas. & .685 & & & & .700 \\
\hline 3 & $\begin{array}{l}\text { I am able to solve challenging real- } \\
\text { life problems. }\end{array}$ & .652 & & & & .783 \\
\hline 4 & $\begin{array}{l}\text { I feel confident in dealing with a } \\
\text { problem. }\end{array}$ & .635 & & & & .747 \\
\hline 5 & $\begin{array}{l}\text { When necessary, I can think of al- } \\
\text { ternatives. }\end{array}$ & .534 & & & & .764 \\
\hline 6 & $\begin{array}{l}\text { I feel confident in identifying the } \\
\text { core of a problem. }\end{array}$ & .518 & & & & .771 \\
\hline 7 & $\begin{array}{l}\text { I am able to look at an issue from a } \\
\text { fresh perspective. }\end{array}$ & .511 & & & & .720 \\
\hline 8 & $\begin{array}{l}\text { I often modify my strategies to } \\
\text { solve a problem when the situation } \\
\text { changes. }\end{array}$ & .472 & & & & .744 \\
\hline 9 & $\begin{array}{l}\text { I am good at keeping in touch with } \\
\text { people. }\end{array}$ & & .886 & & & .691 \\
\hline 10 & $\begin{array}{l}\text { I am good at building relationships } \\
\text { between people. }\end{array}$ & & .730 & & & .691 \\
\hline 11 & $\begin{array}{l}\text { I can build long-term relationships } \\
\text { with people. }\end{array}$ & & .716 & & & .711 \\
\hline 12 & $\begin{array}{l}\text { I can easily establish effective rela- } \\
\text { tionships with people. }\end{array}$ & & .706 & & & .749 \\
\hline 13 & I am good at resolving conflicts. & & .649 & & & .733 \\
\hline 14 & $\begin{array}{l}\text { I am confident in leading others to- } \\
\text { ward common goals. }\end{array}$ & & .543 & & & .731 \\
\hline 15 & $\begin{array}{l}\text { I participate effectively in group } \\
\text { discussions and activities. }\end{array}$ & & .531 & & & .761 \\
\hline 16 & $\begin{array}{l}\text { I have the necessary skills for mak- } \\
\text { ing groups or organizations function } \\
\text { effectively. }\end{array}$ & & .470 & & & .764 \\
\hline 17 & $\begin{array}{l}\text { I will evaluate myself after com- } \\
\text { pleting a task. }\end{array}$ & & & .838 & & .678 \\
\hline 18 & I reflect on myself regularly. & & & .766 & & .653 \\
\hline
\end{tabular}

(c) The Author 2020. Published by the Coalition of Urban and Metropolitan Universities. www.cumuonline.org Metropolitan Universities | DOI 10.18060/23858 | February 21, 2020 
19 I always think how I can improve myself.

20 I consider circumstances when reflecting on how well I have performed.

21 I can analyze an issue comprehensively.

22 I often look at complex issues from .732 .601 different angles.

23 I can understand others' viewpoints .654 .655 when we are making decisions together.

Within the category of civic orientation and engagement, the number of domains was simplified into a three-factor structure. The three factors are named as community commitment and understanding, comprising the original items of the domains of commitment to social betterment and understanding community, with factor loadings between .608 and .861 and $(\alpha=.919)$, caring and respect, comprising the original items of the domains of respecting diversity and empathy and caring for others, with factor loadings between .467 and $.795(\alpha=.907)$, and sense of social responsibility, with factor loadings between .605 and $.789(\alpha=.813)$. The overall variance explained by the category's items was $67.71 \%(\alpha=.946)$. 
Table 7. Results for the Items of the Category of Civic Orientation and Engagement

\begin{tabular}{|c|c|c|c|c|c|}
\hline \multirow[b]{2}{*}{ No } & \multirow[b]{2}{*}{ Item } & \multicolumn{4}{|c|}{ Absolute Value of Factor Loading } \\
\hline & & $\begin{array}{l}\text { Commu- } \\
\text { nity Com- } \\
\text { mitment } \\
\text { and Under- } \\
\text { standing }\end{array}$ & $\begin{array}{c}\text { Caring and } \\
\text { Respect }\end{array}$ & $\begin{array}{c}\text { Sense of } \\
\text { Social Re- } \\
\text { sponsibility }\end{array}$ & $\begin{array}{l}\text { Item-Total } \\
\text { Correlation }\end{array}$ \\
\hline 1 & $\begin{array}{l}\text { I always actively discuss possible im- } \\
\text { provements for our community. }\end{array}$ & .861 & & & .584 \\
\hline 2 & $\begin{array}{l}\text { I can identify useful resources of a com- } \\
\text { munity. }\end{array}$ & .822 & & & .724 \\
\hline 3 & $\begin{array}{l}\text { I think about how I can serve the com- } \\
\text { munity after graduating. }\end{array}$ & .733 & & & 639 \\
\hline 4 & $\begin{array}{l}\text { I can identify challenges in the commu- } \\
\text { nity. }\end{array}$ & .727 & & & .709 \\
\hline 5 & $\begin{array}{l}\text { I can investigate the challenges faced by } \\
\text { people in need in a community. }\end{array}$ & .726 & & & .726 \\
\hline 6 & $\begin{array}{l}\text { I will contribute my abilities to make the } \\
\text { community a better place. }\end{array}$ & 692 & & & .735 \\
\hline 7 & $\begin{array}{l}\text { I can identify issues that are important } \\
\text { for a disadvantaged community. }\end{array}$ & 675 & & & .726 \\
\hline 8 & $\begin{array}{l}\text { I will play my part to reduce social prob- } \\
\text { lems. }\end{array}$ & .608 & & & .719 \\
\hline 9 & $\begin{array}{l}\text { I respect the needs of people from differ- } \\
\text { ent backgrounds. }\end{array}$ & & .795 & & .645 \\
\hline 10 & $\begin{array}{l}\text { I appreciate the ideas of people from dif- } \\
\text { ferent backgrounds. }\end{array}$ & & .789 & & .693 \\
\hline 11 & $\begin{array}{l}\text { I am willing to try to understand people } \\
\text { whose background is different from } \\
\text { mine. }\end{array}$ & & .751 & & .736 \\
\hline 12 & $\begin{array}{l}\text { I can respect people whose background } \\
\text { is different from mine. }\end{array}$ & & .705 & & .576 \\
\hline 13 & I consider others' points of view. & & .685 & & .690 \\
\hline 14 & I care about others. & & .478 & & .746 \\
\hline 15 & I observe others' feelings and emotions. & & .467 & & .692 \\
\hline 16 & $\begin{array}{l}\text { I believe that everybody should be en- } \\
\text { couraged to participate in civic affairs. }\end{array}$ & & & .789 & .622 \\
\hline 17 & $\begin{array}{l}\text { I believe that taking care of people who } \\
\text { are in need is everyone's responsibility. }\end{array}$ & & & .750 & 681 \\
\hline 18 & $\begin{array}{l}\text { I feel obligated to help those who are less } \\
\text { fortunate than me. }\end{array}$ & & & .605 & .700 \\
\hline
\end{tabular}

(c) The Author 2020. Published by the Coalition of Urban and Metropolitan Universities. www.cumuonline.org Metropolitan Universities | DOI 10.18060/23858 | February 21, 2020 
Lastly, the items within the category of self-awareness reflected the designated structure with three resultant factors. These are self-efficacy, renamed from self-esteem, with relevant items retained, with factor loadings between .736 and $.842(\alpha=.859)$, self-understanding, with factor loadings between .527 and $.901(\alpha=.845)$, and commitment to self-improvement, with factor loadings between .660 and $.941(\alpha=.829)$. The overall variance explained by the category's items was $72.01 \%(\alpha=.922)$.

Table 8. Results for the Items of the Category of Self-awareness

\begin{tabular}{|c|c|c|c|c|c|}
\hline \multirow[b]{2}{*}{ No } & \multirow[b]{2}{*}{ Item } & \multicolumn{4}{|c|}{ Absolute Value of Factor Loading } \\
\hline & & Self-efficacy & $\begin{array}{l}\text { Self-under- } \\
\text { standing }\end{array}$ & $\begin{array}{c}\text { Commitment } \\
\text { to Self-im- } \\
\text { provement }\end{array}$ & $\begin{array}{l}\text { Item-Total } \\
\text { Correlation }\end{array}$ \\
\hline 1 & $\begin{array}{l}\text { I am satisfied with my achieve- } \\
\text { ment so far. }\end{array}$ & .842 & & & .644 \\
\hline 2 & Most things I do, I do well. & .830 & & & .694 \\
\hline 3 & I have many good qualities. & .770 & & & .761 \\
\hline 4 & I am positive about myself. & .736 & & & .721 \\
\hline 5 & $\begin{array}{l}\text { I know my strengths and weak- } \\
\text { nesses. }\end{array}$ & & .901 & & .639 \\
\hline 6 & $\begin{array}{l}\text { I have a clear picture of what I } \\
\text { am like as a person. }\end{array}$ & & .877 & & .642 \\
\hline 7 & $\begin{array}{l}\text { I have a clear understanding of } \\
\text { my own values and principles. }\end{array}$ & & .631 & & .743 \\
\hline 8 & I know what I need in my life. & & .527 & & .700 \\
\hline 9 & $\begin{array}{l}\text { I look out for new skills or } \\
\text { knowledge to acquire. }\end{array}$ & & & .941 & .641 \\
\hline 10 & I am always motivated to learn. & & & .762 & .667 \\
\hline 11 & $\begin{array}{l}\text { I always keep my knowledge and } \\
\text { skills up-to-date. }\end{array}$ & & & .660 & .736 \\
\hline
\end{tabular}




\section{Conclusions}

The Emergent Model and Instrument for Service-Learning Outcomes in Hong Kong

The EFA results, given above, indicate a four-category, 11 domain model for student learning outcomes. This emergent Hong Kong model is based on the modified conceptual framework that we arrived at by adjusting a preliminary model from western literature, in the light of educational reforms and the observation that Confucian values appear to have shaped the local adaptation of service-learning in Hong Kong. In our Hong Kong model, the first category, knowledge application, comprises a single eponymous domain. The second category, personal and personal skills, comprises four domains: creative problem-solving skills, relationship and team skills, reflection skills, and critical thinking skills. The third category, civic orientation and engagement, comprises three domains: caring and respect, community commitment and understanding, and sense of social responsibility. The fourth category, self-awareness, comprises three domains: self-efficacy, self-understanding, and commitment to self-improvement.

There are four differences from the modified conceptual framework that was created before the EFA (see Table 3). These involve the combination of pairs of sub-domains into the following higher-order domains: creative problem-solving skills, which is combining creativity and problem solving skills; relationship and team skills, which is combining relationship skills and team skills; caring and respect, which is combining empathy and caring for others with respecting diversity; and community commitment and understanding, which is combining commitment to social betterment with understanding community.

Contrasts with the West

The Hong Kong model still bears some resemblance to the preliminary conceptual framework developed from western literature, which has three categories, academic enhancement, personal growth, and civic learning (e.g. Elyer \& Giles, 1999; Felten \& Clayton, 2011). There are, however, three main differences between the Hong Kong framework and the western framework. First, in the Hong Kong model, the category of knowledge application refers to the generic ability to apply knowledge and does not refer to other forms of academic enhancement that could be measured by course instructors through graded assignments. A second difference is that our Hong Kong model contains a separate category of self-awareness, as distinct from other aspects of personal growth that we identify as another category of personal and professional skills.

There is also a third difference, which reflects contrasting emphases between the civic orientation and engagement category in the Hong Kong model and the civic learning category in the western model. Within the latter model, civic learning emphasizes democracy, social justice, and joint action (Battistoni, 1997; Einfeld \& Collins, 2008; Mitchell, 2008; Wade, 1997). As Battistoni (1997), states: “The civic view ... focuses not on altruism but on enlightened self-interest ...

(C) The Author 2020. Published by the Coalition of Urban and Metropolitan Universities. www.cumuonline.org 
The idea is that ... free democratic communities depend on mutual responsibility and that rights without obligations are ultimately not sustainable.”

By contrast, the Hong Kong model appears to invoke what Battistoni (1997) refers to as a "philanthropic" view of service-learning, based on the notion that "the well-off are obligated to help the less advantaged, though they do not conceive of those served as being part of their own communities” (Battistoni, 1997). This philanthropic orientation is evident in several items in our instrument within the category of civic orientation and engagement, such as the following three items. Under sense of social responsibility, item 18 is "I feel obligated to help those who are less fortunate than me;" under caring and respect, item 11 is: "I am willing to try to understand people whose background is different from mine;" and under community commitment and understanding, item 7 is "I can identify issues that are important for a disadvantaged community."

Allusions to democracy and joint action are not entirely absent from the Hong Kong instrument. Thus, item 16 under sense of social responsibility is, "I believe that everybody should be encouraged to participate in civic affairs.” However, the overall emphasis is in alignment with the previous argument that the mainstream approach to civic education in Hong Kong is relatively depoliticized, emphasizing spirituality, self-cultivation, harmonious relationships, and preservation of the status quo (Lee, 2004).

Practical Implications

As a result of the validation exercise conducted thus far, the length of S-LOMS has been reduced from 103 to 56 items under the 11 outcome domains. S-LOMS has achieved satisfactory dimensionality and reliability, and has a clear domain structure with broad similarities with previous research studies, while reflecting local adaptation to educational norms and policies in Hong Kong. Furthermore, the factor structure and item compositions have been confirmed with a large sample ( $\mathrm{N}=400)$, which conforms with the benchmark respondent to item ratio of five to one in factor analysis (Stevens, 2009). Such results provide a strong empirical foundation for the SLOMS in terms of its internal consistency. We believe that the clear and strong factor structure of the instrument will enable it to be of considerable practical convenience both for institutions and for service-learning practitioners and researchers.

Looking ahead, our work for validating S-LOMS still requires some additional steps. First, the results obtained from the EFA and reported above need to be confirmed with another sample by means of Confirmatory Factor Analysis (CFA), before going on to engage in further testing for test-retest reliability. Subsequently, S-LOMS will be tested for criterion validity by administering it on a pre- and post-test basis with students, who are undertaking actual service-learning courses. This will enable us to investigate whether, for example, the domains in which students indicate their greatest developmental gains match the priority domains indicated by instructors. We will also investigate the sensitivity of the instrument to developmental outcomes for students

(C) The Author 2020. Published by the Coalition of Urban and Metropolitan Universities. www.cumuonline.org 
across different course types, service types, academic disciplines, and other factors. In addition, more item reduction work will be conducted with the aim of further reducing the S-LOMS to three items for each domain.

Furthermore, although S-LOMS has been designed for the Hong Kong context, we intend also to investigate its validity in other Asian contexts such as Taiwan and Singapore. As Hofstede (1980) revealed in his cultural assessment study, no two Asian cultures and regions should be assumed to be the same, despite many of them having been greatly influenced by Confucian traditions, such as Hong Kong, Singapore, Taiwan, and Japan. Differences between locations in terms of broader educational policies may constitute another source of variation regarding the local adaptation of service-learning practices. In the event that S-LOMS is found to be valid in other Asian contexts, this would enable comparative studies of the developmental impacts of servicelearning for students in different locations, which in turn would address a broader gap regarding the lack of service-learning research in Asia (e.g. Shek \& Chan, 2013; Xing and Ma, 2010).

\section{Limitations}

Besides the need to take further steps to validate S-LOMS in Hong Kong and other Asian contexts, the discovery of four higher-order factors implies that some developmental outcome domains may not be easily differentiated by means of a self-reported instrument. Assessing developmental impact within those domains may require additional or alternative methods for data collection, such as onsite observation, interviews, focus groups, and archival sources (e.g. Bringle et al., 2004). In addition, we have already mentioned that assessments of the impact of service-learning on students' understanding of subject knowledge may be more appropriately based on their performance on graded assignments and examinations. Accordingly, we acknowledge that a measurement instrument should not be regarded as a panacea, and that advancing understanding of the impact of service-learning on students in Asia will likely require multiple methods.

\section{Author Note}

This paper is the result of a cross-institutional project named "Cross-institutional Capacity Building for Service-Learning in Hong Kong Higher Education Institutions,” aiming at enhancing and supporting the development of service-learning as an effective pedagogical strategy under the collaboration of Lingnan University, The Hong Kong Polytechnic University, Hong Kong Baptist University, and The Education University of Hong Kong. The project was launched in 2017, and has been funded by the University Grants Committee (UGC) of the Hong Kong Special Administrative Region (HKSAR) government. The authors wish to thank the UGC for funding the project, and the above institutions for their participation in the process of scale development and

(C) The Author 2020. Published by the Coalition of Urban and Metropolitan Universities. www.cumuonline.org 
validation. We are particularly grateful to professor James Yue On Ko of The Education University of Hong Kong and Dr. Kam Por Kwan of The Hong Kong Polytechnic University for their advice on statistical analysis.

(C) The Author 2020. Published by the Coalition of Urban and Metropolitan Universities. www.cumuonline.org Metropolitan Universities | DOI 10.18060/23858 | February 21, 2020 


\section{References}

Astin, A. W. \& Sax, L. J. (1998). How undergraduates are affected by service participation. Journal of College Student Development, 39 (3), 251-263. Retrieved from https://digitalcommons.unomaha.edu/slcehighered/7.

Astin, A. W., Vogelgesang, L. J., Ikeda, E. K., \& Yee, J. A. (2000). How service learning affects students. Los Angeles, CA: Higher Education Research Institute, UCLA. Retrieved from https://digitalcommons.unomaha.edu/slcehighered/144.

Ash, S. L., Clayton, P. H. (2009). Generating, deepening, and documenting learning: The power of critical reflection for applied learning. Journal of Applied Learning in Higher Education, 1, 25-48. Retrieved from https://scholarworks.iupui.edu/bitstream/handle/1805/4579/ash2009-generating.pdf.

Battistoni, R. M. (1997). Service learning and democratic citizenship. Theory and Practice, 36(3), 150 - 156. Retrieved from https://digitalcommons.unomaha.edu/slceslgen/86.

Boateng, G. O., Neilands T. B., Frongillo E., Melgar-Quiñonez H. R., \& Young S. L. (2018). Best practices for developing and validating scales for health, social, and behavioral research: a primer. Frontiers in Public Health,149(6),1-18. https://doi.org/10.3389/fpubh.2018.00149.

Bringle, R. G., \& Hatcher, J. A. (1999). Reflection in service learning: Making meaning of experience. Educational Horizons, 179-185. Retrieved from https://digitalcommons.unomaha.edu/slceeval/23.

Bringle, R. G., Philips, M. A., \& Hudson, M. (2004). The measure of service learning: research scales to access student experiences. Washington, DC: American Psychological Association.

Celio, C. I., Durlak, J., \& Dymnicki, A. (2011). A meta-analysis of the impact of service-learning on students. Journal of Experiential Education, 34(2), 164-181. https://doi.org/10.5193/jee34.2.164.

Chan, A. C. M., Ma, H. K. C., \& Fong, F. M. S. (2006). Service-learning and research scheme: The Lingnan model. Hong Kong: Office of Service-Learning, Lingnan University. Retrieved from https://commons.ln.edu.hk/osl_book/5/.

Chan, S. (1999). The Chinese learner - a question of style. Education \& Training, 41, 294 - 304. https://doi.org/10.1108/00400919910285345. 
Chan, S. C. F., \& Ngai, G. (2014), Service-Learning as a core academic component in undergraduate programmes: A brief introduction to the Hong Kong Polytechnic University model. The Journal of Development Communication, 25(1), 84-99. Retrieved from http://ira.lib.polyu.edu.hk/bitstream/10397/64558/1/Chan_Service Learning_Core_Academic.pdf.

Conway, J. M., Amel, E. L., \& Gerwien, D. P. (2009). Teaching and learning in the social context: A meta-analysis of service learning's effects on academic, personal, social, and citizenship outcomes. Teaching of Psychology, 36(4), 233-245.

https://doi.org/10.1080/00986280903172969.

Daynes, G., \& Wygant, S. (2003). Service-learning as a pathway to civic engagement: A comparative study. Metropolitan Universities, 14(3), 84-96. Retrieved from https://journals.iupui.edu/index.php/muj/article/view/20123.

DeVellis, R. F. (2003). Scale development: theory and application. Los Angeles, CA: Sage Publications.

Driscoll, A., Holland, B., Gelmon, S., \& Kerrigan, S. (1996). An assessment model for servicelearning: Comprehensive case studies of impact on faculty, students, community and institutions. Michigan Journal of Community Service Learning, 3, 66-71.

Education and Manpower Bureau. (2001). Learning to learn - The way forward in curriculum development. Hong Kong: Education and Manpower Bureau. Retrieved from https://www.edb.gov.hk/en/curriculum-development/cs-curriculum-doc-report/wf-in-cur/index.html.

Education and Manpower Bureau (2005). The New academic structure for senior secondary education and higher education: Action plan for investing in the future of Hong Kong. Hong Kong: Education and Manpower Bureau. Retrieved from https://334.edb.hkedcity.net/doc/eng/report_e.pdf.

Einfeld, A., \& Collins, D. (2008). The relationships between service-learning, social justice, multicultural competence, and civic engagement. Journal of College Student Development, 49(2), 95-109. https://doi.org/10.1353/csd.2008.0017.

Eyler, J. (2010). What international service learning research can learn from research on service learning. In R. G. Bringle, J. A. Hatcher, and S. G. Jones (eds.), International service learning: Conceptual frameworks and research (Vol. 2, pp. 225 - 242). Sterling, Va.: Stylus.

(c) The Author 2020. Published by the Coalition of Urban and Metropolitan Universities. www.cumuonline.org 
Eyler, J. S., \& Giles, D. E. (1999). Where's the learning in service-learning? San Francisco, CA: Jossey-Bass.

Eyler, J. S., Giles, D. E., \& Braxton, J. (1997). The impact of service-learning on college students. Michigan Journal of Community Service Learning, 4(1), 5-15. Retrieved from http://hdl.handle.net/2027/spo.3239521.0004.101.

Eyler, J. S., Giles, D. E., Stenson, C. M., and Gray, C. J., (2001). At a glance: What we know about the effects of service-learning on college students, faculty, institutions and communities, 1993-2000. (3rd ed.) Nashville, Tenn.: Vanderbilt University Press.

Felten, P., \& Clayton, P. H. (2011). Service-Learning. New Directions for Teaching and Learning, 128, 75-84. https://doi.org/10.1002/tl.470.

Freake, H. (2013). Curricular designs for general education at the UGC-supported universities in Hong Kong. In J. Xing, P. S. Ng, and C. Y. Cheng (eds.), General education and the development of global citizenship in Hong Kong, Taiwan and mainland China (pp. 105-120). New York: Routledge.

Giles, D. E., \& Eyler, J. (1994). The theoretical roots of service-learning in John Dewey: Toward a theory of service-learning. Michigan Journal of Community Service Learning, 1(1), 77-85. Retrieved from http://hdl.handle.net/2027/spo.3239521.0001.109.

Godfrey, P. C., Illes, L. M., \& Berry, G. (2005). Creating breadth in business education through service-learning. Academy of Management Learning \& Education 4(3), 309-323. https://doi.org/10.5465/amle.2005.18122420.

Hatcher, J., Bringle, R., \& Muthiah, R. (2004). Designing effective reflection: What matters to service-learning? Michigan Journal of Community Service Learning, 11(1), 38-46. Retrieved from http://hdl.handle.net/2027/spo.3239521.0011.104.

Hinkin, T. R. (1995). A review of scale development practices in the study of organizations. Journal of Management, 21(5), 967-988. https://doi.org/10.1177/014920639502100509.

Hinkin, T. R., Tracey, J. B., \& Enz, C. A. (1997). Scale construction: Developing reliable and valid measurement instruments. Journal of Hospitality \& Tourism Research, 21(1), 100-120. https://doi.org/10.1177/109634809702100108.

Hofstede, G. (1980). Culture's consequences: International differences in work-related values. London and Beverly Hills: Sage.

(C) The Author 2020. Published by the Coalition of Urban and Metropolitan Universities. www.cumuonline.org Metropolitan Universities | DOI 10.18060/23858 | February 21, 2020 
Hofstede, G. (1983). Dimensions of national cultures in fifty countries and three regions. In J. B. Deregowski, S. Dziurawiec, and R. C. Annis (Eds.), Expiscations in cross-cultural psychology (pp. 335-355). Lisse, Netherlands: Swets and Zeitlingers.

Howard, J. (Ed.). (2001). Service-learning course design workbook. Ann Arbor, MI: OCSL Press. Retrieved from https://eric.ed.gov/?id=ED457774.

Jacoby, B. (1996). Service-Learning in higher education: concepts and practices. San Francisco: Jossey-Bass.

Kennedy, P. (2002). Learning cultures and learning styles: myth-understandings about adult (Hong Kong) Chinese learners. International Journal of Lifelong Education, 21(5), 430-445. https://doi.org/10.1080/02601370210156745.

Lee, W. O. (1996). The cultural context for Chinese learners: conceptions of learning in the Confucian tradition. In D. Watkins and J. Biggs (Eds.) The Chinese learner: Cultural, psychological and contextual influences (pp. 25-41). Hong Kong: The Comparative Education Research Centre, Faculty of Education, University of Hong Kong.

Lee, W. O. (2004). Concepts and issues of Asian citizenship: spirituality, harmony and individuality. In D. Grossman, K. Kennedy, G. Fairbrother \& W.O. Lee (Eds.), Citizenship education in Asia and the Pacific: Concepts and issues. Hong Kong: Comparative Education Research Centre, University of Hong Kong.

Leung, Y. W., \& Yuen T. W. W. (2012). Competition between politicized and depoliticized versions of civic education curricula: the case of Hong Kong. Citizenship, Social and Economics Education, 11(1), 45 - 56. https://doi.org/10.2304/csee.2012.11.1.45.

Lo, K. W. K., Kwan, K. P., Chan, S. C. F., \& Ngai, G. (2016). Cross-Cultural Validation of the Global Citizenship Scale for Measuring Impacts of International Service-Learning in Hong Kong Setting. Paper presented at the 3rd International Conference on Service-Learning, Hong Kong.

Lundy, B. L. (2007). Service learning in life-span developmental psychology: Higher exam scores and increased empathy. Teaching of Psychology, 34(1), 23-27. https://doi.org/10.1207/s15328023top3401_5.

(C) The Author 2020. Published by the Coalition of Urban and Metropolitan Universities. www.cumuonline.org 
Ma, C. (2018). Service-learning development in higher education in Hong Kong. In T. W. Lim \& W. X. Li (Eds), Studying Hong Kong: 20 years of political, economic and social developments (pp. 43-61). New Jersey: World Scientific. https://doi.org/10.1142/9789813223554_0004.

Ma, C. H. K., \& Chan, A. C. M. (2013). A Hong Kong university first: Establishing servicelearning as an academic credit-bearing subject. Gateways: International Journal of Community Research and Engagement, 6, 178-198. https://doi.org/10.5130/ijcre.v6i1.3286.

Ma, H. K. C., Chan, C. W. F., Tse, P. H. (2019). A common outcome measurement for servicelearning in Hong Kong. Journal of Higher Education Outreach and Engagement, 23(3), 319.

Ma, H. K. C., \& Lo, D. F. Y. (2016). Service-learning as an independent course: Merits, challenges, and ways forward. International Journal of Research on Service Learning and Community Engagement, 4(1), 1-14. Retrieved from http://journals.sfu.ca/iarslce/index.php/journal/article/view/187/121

Mitchell, T. D. (2008). Traditional vs. critical service-learning: engaging the literature to differentiate two models. Michigan Journal of Community Service Learning, 14(2), 50 - 65. Retrieved from http://hdl.handle.net/2027/spo.3239521.0014.205.

Morgado, F. F. R., Meireles J. F. F., Neves, C. M., Amaral, A. C. S., Ferreira, M. E. C. (2018). Scale development: Ten main limitations and recommendations to improve future research practices. Psicologia: Reflexão e Crítica, 30(1). https://doi.org/10.1186/s41155-016-0057-1.

Ngai, S. S. (2006). Service-learning, personal development, and social commitment: A case study of university students in Hong Kong. Adolescence, 41, 165-176. Retrieved from https://www.ncbi.nlm.nih.gov/pubmed/16689448.

Ngai, S. S. (2009). The effects of program characteristics and psychological engagement on service-learning outcomes: A study of university students in Hong Kong. Adolescence, 44, 375389. Retrieved from https://www.ncbi.nlm.nih.gov/pubmed/19764273.

Novak, J. M., Markey, V., \& Allen, M. (2007). Evaluating cognitive outcomes of service learning in higher education: A meta-analysis. Communication Research Reports, 24(2), 149-157. https://doi.org/10.1080/08824090701304881. 
O'Connor, B. P. (2000). SPSS and SAS programs for determining the number of components using parallel analysis and Velicer's MAP test. Behavior Research Methods, Instruments, \& Computers, 32(3), 396-402. https://doi.org/10.3758/bf03200807.

Olney, C. A., \& Grande, S. E. (1995). Validation of a scale to measure development of social responsibility. Michigan Journal of Community Service Learning, 2, 43-53. Retrieved from http://hdl.handle.net/2027/spo.3239521.0002.104.

Permaul, J. S. (2010). A cross-cultural service-learning program model: W. T. Chan fellowships program. In J. Xing, \& C. Ma (Eds.), Service learning in Asia: Curricular models and practices (pp. 143 - 155). Hong Kong University Press. https://doi.org/10.5790/hongkong/9789888028467.003.0011.

Prentice, M. (2007). Service learning and civic engagement. Academic Questions, 20, 135-145. https://doi.org/10.1007/s12129-007-9005-y

Rama, D. V. (1998). Learning by doing: Concepts and models for service-learning in accounting. AAHE's series on service-learning in the disciplines. Washington, D.C.: American Association for Higher Education. Retrieved from https://eric.ed.gov/?id=ED449726.

Ramsay, W. R. (2017). Service-Learning: Memories and perspectives. In R. Shumer (Ed.), Where's the wisdom in service-learning? NC: Information Age Publishing.

Reeb, R. N., Katsuyama, R. M., Sammon, J. A., \& Yoder, D. S. (1998). The community service self-efficacy scale: evidence of reliability, construct validity, and pragmatic utility. Michigan Journal of Community Service Learning, 5, 48-57. Retrieved from http://hdl.handle.net/2027/spo.3239521.0005.105.

Richard, D., Keen, C., Hatcher, J. A., \& Pease, H. A. (2017). Pathways to adult civic engagement: Benefits of reflection and dialogue across difference in higher education service-learning programs. Michigan Journal of Community Service Learning, 23(1), 60-74.

http://dx.doi.org/10.3998/mjcsloa.3239521.0023.105.

Rodrigues, C. A. (2005). Culture as a determinant of the importance level business students place on ten teaching learning techniques. Journal of Management Development 24(7), 608-21. https://doi.org/10.1108/02621710510608740.

Rosenberg, M. (1965). Society and the adolescent self image, Princeton. NJ: Princeton University Press. https://doi.org/10.1515/9781400876136.

(c) The Author 2020. Published by the Coalition of Urban and Metropolitan Universities. www.cumuonline.org 
Saltmarsh, J. (2005). The civic promise of service learning. Liberal Education, 91(2), 50-55. Retrieved from https://files.eric.ed.gov/fulltext/EJ697354.pdf.

Shek, D. \& Chan, S. (2013) Service-learning from the views of university teachers: a qualitative study based on focus groups. International Journal of Adolescent Medicine and Health, 25(4), 385-393. https://doi.org/10.1515/ijamh-2013-0036.

Shek, D. T. L., Yu, L., Wu, F. K. Y., \& Chai, W. Y. (2015). General university requirements at Hong Kong Polytechnic University: evaluation findings based on student focus groups. Assessment \& Evaluation in Higher Education, 40(8), 1017-1031. https://doi.org/10.1080/02602938.2014.960362.

Shumer, R., Stanton, T. K. and Giles D. E., Jr. (2017), History and precursors of service-learning theory, development and research. In Robert Shumer (Ed.) Where's the wisdom in servicelearning? NC: Information Age Publishing.

Simons, L., \& Cleary, B. (2006). The influence of service learning on students' personal and social development. College Teaching, 54(4), 307-319. https://doi.org/10.3200/ctch.54.4.307319.

Siu, P. Y. C., Tang, H. H. E., \& Lai, C. O. A. (2013). Teaching and learning global citizenship through service-learning: The success story of cross-border service-learning summer institute, Lingnan University, Hong Kong. Paper presented at 4th Asia-Pacific Regional Conference on Service-Learning: Service-Learning as a Bridge from Local to Global: Connected World, Connected Future. Hong Kong and Guangzhou, China. Retrieved from https://commons.ln.edu.hk/cgi/viewcontent.cgi?referer=https://scholar.google.com/\&httpsredir=1\&article $=1073 \&$ context $=$ osl_conference.

Snell, R. S., Chan, M. Y. L., Ma, C. H. K., \& Chan, C. K. M. (2015a). Developing civic-mindedness in undergraduate business students through service-learning projects for civic engagement and service leadership practices for civic improvement. Asian Journal of Business Ethics, 4(1), 73-99. https://doi.org/10.1007/s13520-015-0044-0.

Snell R. S., Chan, Y. L. M., Ma, H. K. C., Chan, K. M. C. (2015b). A road map for empowering undergraduates to practice service leadership through service-learning in teams. Journal of Management Education, 39(3), 372-399. https://doi.org/10.1177/1052562914545631.

Snell, R. S., Chan, M. Y. L., Wu, C. X., Chan C. W. Y. (2019). Service leadership emergence through service-learning internships in Hong Kong. Michigan Journal of Community Service Learning, 25(2), 167-199.

(C) The Author 2020. Published by the Coalition of Urban and Metropolitan Universities. www.cumuonline.org 
Stevens, J. P. (2009). Applied multivariate statistics for the social sciences ( $5^{\text {th }}$ ed.). New York: Routledge. https://doi.org/10.4324/9780203843130.

Toncar, M. F., Reid, J. S., Burns, D. J., Anderson, C. E., \& Nguyen, H. P. (2006). Uniform assessment of the benefits of service learning: the development, evaluation, and implementation of the SELEB scale. The Journal of Marketing Theory and Practice, 14(3), 223-238. https://doi.org/10.2753/mtp1069-6679140304.

Wade, R. (Ed.). (1997). Community service-learning: A guide to including service in the public school curriculum. Albany: State University of New York Press.

Warren, J. L. (2012). Does service learning increase student learning? A meta-analysis. Michigan Journal of Community Service Learning, 18(2), 56-61. Retrieved from http://hdl.handle.net/2027/spo.3239521.0018.205.

University Grants Committee. (2010). Aspirations for the higher education system in Hong Kong: Report of the University Grants Committee. Hong Kong. Retrieved from https://www.ugc.edu.hk/eng/ugc/about/publications/report/her2010/her2010.html

Xing, J., \& Ma, C. (2010). Service-learning in Asia: Curricular models and practices. Hong Kong University Press. https://doi.org/10.5790/hongkong/9789888028467.001.0001.

Yorio, P. L., \& Ye, F. (2012). A meta-analysis on the effects of service-learning on the social, personal, and cognitive outcomes of learning. Academy of Management Learning \& Education, 11(1), 9-27. https://doi.org/10.5465/amle.2010.0072.

(c) The Author 2020. Published by the Coalition of Urban and Metropolitan Universities. www.cumuonline.org Metropolitan Universities | DOI 10.18060/23858 | February 21, 2020 